\title{
A favor de uma sociologia transnacional da laicidade na ultramodernidade contemporânea ${ }^{1}$
}

\author{
In favor of a transnational sociology on laicity in \\ contemporary ultramodernity
}

Jean-Paul Willaime*

A discussão crítica entabulada com meu amigo Jean Baubérot² (JB) por ocasião da publicação, em 2008, de minha obra intitulada Le retour du religieux dans la sphère publique concentrou-se, sobretudo, na lição de laicidade que ele deu a Nicolas Sarkozy depois dos seus discursos em Roma e em Riad referentes à religião (2008). Embora o panfleto de $\mathrm{JB}^{3}$ seja, a meu ver, mais um ato político do que acadêmico, ele oferece mesmo assim os principais elementos de suas análises sobre a laicidade, análises que eu conhecia através de suas obras anteriores, mas que apresentam aqui uma discrepância em relação às posições desenvolvidas por ele em 2006, em sua obra intitulada L'intégrisme républicain contre la laïcité. JB teria se deixado levar por sua paixão política? Sem dúvida. Em todo caso, há momentos em que me apoio em JB 2006 para criticar JB 2008.

* Sociólogo da religião, diretor da École Pratique des Hautes Études, diretor do Institut Européen en Sciences des Religions, presidente da International Society for the Sociology of Religion, membro do Groupe, Sociétés, Religions, Laicités. <jean-paul.willaime@gsrl.cnrs.fr>.

1 Este texto foi publicado originalmente na Archives des Sciences Sociales des Religions, v. 54, n. 146, 2009, p. 201-218. A tradução e a publicação foram autorizadas pelo autor e pelo editor do periódico. A tradução do francês para o português foi efetuada por Vanise Dresch.

2 Amigo de longa data de Jean Baubérot, fui nomeado em 1992, vindo da Universidade de Estrasburgo II, para a direção de estudos "História e sociologia do Protestantismo", no departamento de Ciências Religiosas da EPHE, depois de Jean Baubérot ter assumido uma cátedra intitulada "História e sociologia da laicidade", que acabara de ser criada na EPHE, em 1991. Em 2002, fui o sucessor de Jean Baubérot na direção do Grupo Sociedades, Religiões e Laicidades (UMR EPHE-CNRS), antes de transferir o cargo, em 2008, para Philippe Portier, novo titular da direção de estudos "História e sociologia da laicidade" que Jean Baubérot ocupou até 2007.

3 No preâmbulo de L'intégrisme républicain contre la laïcité, JB escreve: "Não decidi escrever um panfleto" (2006, p. 12). Em La laïcité expliquée à M. Sarkozy (2008), ele decidiu fazê-lo.

ก. 2

p. $303-322$

maio-ago. 2011 


\section{Questão de estilo e de enquadramento intelectual}

Para começar, acho importante assinalar de antemão nossas diferenças de estilo e de enquadramento intelectual, pois elas não ficam alheias às nossas discordâncias. JB articula, há muito tempo, em seus estudos sobre a laicidade, análise científica e engajamento militante. Ele mesmo apresenta várias de suas obras como livros cidadãos. Descreve-nos não só o que a laicidade foi no início e o que ela se tornou hoje, como também o que ela deve ser e o que não deve ser. JB realiza ao mesmo tempo - e aí está o interesse incontestável de suas análises - um trabalho de historiador e de sociólogo. Todavia, considerar as escolhas feitas em 1905 como a norma insuperável para o presente é dar um passo muito largo. Tenho dificuldade de compreender esse fundamentalismo histórico. Não é por ter sido uma lei liberal, como JB demonstra, que a Lei de 1905 seja indiscutivelmente o dispositivo jurídico mais bem adaptado para a configuração sociorreligiosa da França contemporânea. Pessoalmente, aprecio mais a sincronia do que a diacronia nesse terreno, sobretudo, nas comparações que estabeleço com os outros países da Europa. As comparações internacionais de JB polarizam-se significativamente entre países que, em matéria de laicidade, desenvolveram abordagens mais ou menos próximas do modelo francês: Turquia, México, Quebec. Sempre me perguntei por que razão ele não desenvolveu análises comparativas sistemáticas com "a concepção americana da laicidade"4, isto é, com a outra grande democracia que aplicou uma estrita separação das Igrejas e do Estado: os Estados Unidos. Provavelmente porque, neste caso, há um distanciamento muito maior em relação à problemática francesa. Carol J. Greenhouse, uma antropóloga de Princeton, explica, de forma convincente, por que o termo francês laicidade é difícil de traduzir para o inglês americano:

A separação das Igrejas e do Estado nos Estados Unidos é mais que uma doutrina jurídica que protege a liberdade religiosa individual, sendo também um enunciado sobre a arquitetura moral dos Estados Unidos. Este enunciado tem um caráter estruturante, no sentido de que estipula que a fonte da ordem moral do Estado deriva das comunidades locais concebidas como comunidades morais - sendo, por conseguinte, um componente do sistema federal dos 'freios e contrapesos'. [...] A dissociação entre a Igreja e o Estado é uma garantia para a liberdade individual $e$, ao mesmo tempo, a prova de uma moralidade miseramente e apenas parcialmente investida nos poderes públicos. É esta implicação estrutural da dissociação entre a Igreja e o Estado, e não a referência à liberdade, que torna o termo laicidade difícil de traduzir (Greenhouse, 2005, p. 210).

4 La conception américaine de la laïcité (sob a direção de Elisabeth Zoller, 2005a). 
O enraizamento histórico francês dos trabalhos de JB sobre a laicidade limita, no meu entender, a despeito do valor intrínseco e do mérito incontestável desses trabalhos, o alcance intelectual de sua sociologia das laicidades.

Enquanto a comissão sobre as relações dos cultos com o poder público, denominada Comissão $\mathrm{Machelon}^{5}$, foi uma comissão jurídica muito técnica que examinou como adaptar os dispositivos jurídicos aplicáveis aos cultos à configuração da França contemporânea, sem alterar, se possível, a Lei de 1905, JB se permite denunciar as "perigosas propostas da Comissão" (2008, p. 210), especialmente porque esta punha em xeque o princípio do não reconhecimento dos cultos. Seria desejável que JB fosse, em relação a esse ponto, mais historiador do que militante, lembrando que a formulação de 1905 é uma forma de significar que é posto fim ao sistema dos cultos reconhecidos, herdado da Concordata de 1801 e dos "Artigos Orgânicos" de 1802. Quanto a condenar a Comissão Machelon por ter desejado estender a toda a França o sistema que prevalece na região da Alsácia-Mosela, trata-se de um puro processo de intenção. Atacar o jurista Jean-Marie Woehrling, sob a alegação de que ele relativiza a oposição entre separação e reconhecimento, não tem validade do ponto de vista acadêmico. O jurista de Estrasburgo concluiu seu estudo muito minucioso a este respeito, publicado nos Archives de Sciences Sociales des Religions, nos seguintes termos:

Podemos nos indagar sobre a pertinência, nos dias de hoje, da oposição entre reconhecimento e separação. O termo culto reconhecido só ganhou destaque a partir da lei da separação. Hoje, todos os autores admitem que, por um lado, se na Velha França os cultos não eram reconhecidos, por outro, a atividade religiosa tem uma recepção (Pierre-Henri Prélot) pelo direito francês, a atividade religiosa é institucionalizada (Danièle Loschak) ou ainda a prática cultural é levada em consideração (Jean-Claude Maestre). Multiplica-se a busca de sinônimos para o reconhecimento. Inversamente, o sistema dos cultos reconhecidos se diz em conformidade com os princípios de neutralidade do Estado e da autonomia dos cultos em relação a ele. No fundo, ouve-se afirmar uma forma de separação IgrejaEstado dentro de um sistema de reconhecimento (1998, p. 50).

Defendi, num artigo também publicado nos Archives de Sciences Sociales des Religions (2005, p. 67-82), que a França praticava, na realidade, uma

\footnotetext{
5 A Comissão ganhou o nome de seu presidente, Jean-Pierre Machelon, decano da faculdade de Direito da Universidade Paris V-René Descartes e diretor de estudos associado à EPHE. Participei dos trabalhos dessa comissão que se desenrolaram do final de 2005 a setembro de 2006.
} 
"laicidade de reconhecimento" das religiões. Em muitos países da Europa, como mostraram diversos juristas (principalmente Silvio Ferrari), há, ao mesmo tempo, a separação Igreja-Estado e diversos sistemas de reconhecimento das religiões, entre os quais as concordatas. Poderíamos também lembrar que, durante os debates de 1905, certos republicanos (notadamente Charles Benoist e Alexandre Ribot) consideravam que a concordata não era incompatível com a separação. Relativizar a oposição entre separação e concordata pode ser chocante e politicamente incorreto de certo ponto de vista francês, mas não deve sê-lo de um ponto de vista acadêmico. O fato de a Comissão Machelon ter se mostrado favorável, no âmbito da separação, a certas formas de reconhecimento das religiões só pode ser visto como incongruente se considerarmos a Lei de 1905 como um dogma intangível. É também uma posição militante (e percebida como jacobina em Estrasburgo) que expressa JB em suas diversas condenações da legislação dos cultos que prevalece na Alsácia-Mosela, enquanto que, em se tratando dos $\mathrm{DOM}^{-\mathrm{TOM}^{6}}$, ele interpreta positivamente o fato de que, nestes casos, a França "deu as costas para o universalismo abstrato" e praticou, até mesmo de forma vergonhosa, certo multiculturalismo ${ }^{7}$.

Em relação a esse estilo e a esse enquadramento intelectual de $\mathrm{JB}$, sou mais reservado em matéria de engajamento militante, convencido de que o trabalho intelectual tem algo de iconoclasta, em particular no que tange às evidências nacionais. Em matéria de laicidade, assim como em outros assuntos, não vejo razão para se ter de pensar na perspectiva francesa. Trinta e três anos passados em Estrasburgo, dos quais dezessete como professor-pesquisador na Universidade (de 1975 a 1992), cooperações franco-alemãs intensas ${ }^{8}$, uma experiência recente de especialista no Conselho da Europa (2007-2008) ${ }^{9}$ e o projeto europeu $\mathrm{REDCo}^{10}$ me sensibilizaram para a diversidade europeia e para a necessidade de desenvolver abordagens transnacionais, ou seja, abordagens que vão além dos enquadramentos intelectuais excessivamente nacionais dos

6 N.T.: Fazem parte da República Francesa, os Departamentos de além-mar (DOM) e os Territórios de Além-mar (TOM).

7 Cf. o capítulo 2 "Laïcité et Outre-Mer", in L'intégrisme républicain contre la laïcité (2006, p. 55 et seq).

8 A última cooperação culminou em: Koenig; Willaime (Eds.) Religionskontroversen in Frankreich und Deutschland, 2008.

9 No âmbito da elaboração do Livre blanc sur le dialogue interculturel "Vivre ensemble dans l'égale dignité", 2008.

${ }^{10}$ Projeto Religion in Education. A Contribution to Dialogue or a Factor of Conflict in Transforming Societies of European Countries, realizado entre 2006 e 2009 no âmbito do VI PCRD da União Europeia. 
objetos de estudo considerados ${ }^{11}$. É com esse pano de fundo de diferenças de estilo e de enquadramento intelectuais que mantenho com JB pontos de concordância e alguns pontos de discordância. Vejamos, primeiramente, os nossos importantes pontos de convergência.

\section{Nossos pontos de convergência}

Em muitos aspectos, JB compartilha, à sua maneira, de minha análise que caracteriza a ultramodernidade contemporânea como uma radicalização da secularização. Hoje, a secularização não concerne somente ao religioso, mas também às próprias instituições seculares, que, com a afirmação de suas pretensões normativas e progressistas, contribuíram para a secularização do religioso. Foi isso que designei por secularização ao quadrado (a secularização na potência 2 = secularização $\left.{ }^{2}\right)$. O que significa? Em diversas contribuições (2006a, p. 755-783; 2006b, p. 73-85), apoiando-me nas análises de Anthony Giddens e Ulrich Beck, desenvolvi a tese da ultramodernidade como secularização da modernidade. Enquanto, num primeiro tempo, a modernidade ocidental foi o movimento mais a certeza - a mudança realizada em nome da crença missionária no progresso - hoje, a modernidade ocidental é a mudança mais a incerteza. Enquanto a modernidade esteve muito ligada à afirmação das sociedades nacionais e aos projetos civilizatórios (tanto internamente com a educação escolar quanto externamente com as colonizações), a ultramodernidade relativiza os marcos nacionais do exercício da soberania política bem como os magistérios educativos e civilizatórios. A modernidade esteve ligada à afirmação dos Estados-nações, ao passo que a ultramodernidade está ligada às dimensões transnacionais das trocas de bens e saberes, bem como à afirmação transnacional dos direitos humanos. As lógicas de incerteza e as dimensões transnacionais características da ultramodernidade opõem-se às lógicas de certeza e às dimensões nacionais da modernidade. Passa-se das certezas modernas das sociedades nacionais às incertezas ultramodernas da sociedade-mundo. A ultramodernidade representa um processo de secularização da modernidade, de desmitologização dos ideais seculares, em nome dos quais, justamente, a modernidade contribuiu para a secularização do religioso. É o desencantamento dos desencantadores. O próprio movimento de modernização crítica que atingiu o religioso alcança agora todas as esferas de atividade e todas as instituições, inclusive a própria modernidade. Na crítica dirigida a mim, ao tomar especialmente o exemplo da

11 Foi também uma experiência intelectual coletiva que realizei no âmbito do programa de cooperação franco-americano intitulado Pluralisme, Politique, Religion, em parceria com John Bowen (Washington University, Saint-Louis, Missouri) e com o apoio do Partner University Fund. 
família e da medicina, JB comete um contrassenso em relação ao meu emprego de sociedade tradicional. Não nego absolutamente que a sociedade moderna, nas fases de modernidade ascendente e de modernidade estabelecida, constitui uma vigorosa ruptura com a sociedade tradicional anterior. A confusão vem do fato de que, baseando-me nas análises de Ulrich Beck, defendo que a própria sociedade moderna, em sua fase burgo-industrial, diante das radicalizações que a ultramodernidade representa, torna-se uma sociedade tradicional. Emprego, portanto, a ideia de sociedade tradicional de maneira evolutiva para dizer que o regime da ultramodernidade faz a própria sociedade moderna aparecer como "tradicional", ainda que esta tenha representado importantes rupturas com uma sociedade anterior dita "tradicional". Assim, o fato de que a família nuclear tenha representado uma ruptura perante os modelos familiares anteriores "congruentes com a modernidade ascendente" não impede que ela seja tida hoje como um modelo tradicional ante as reconfigurações contemporâneas das relações conjugais e parentais.

JB não fala de ultramodernidade, e, sim, de modernidade tardia, adotando o emprego de late modernity ${ }^{12}$. Porém, no fundo, compartilhamos da mesma análise de uma transferência de encantamento do religioso para o secular. JB menciona, além da escola e do político, o campo da medicina. Para constatarmos isso, basta lermos as seguintes afirmações extraídas de L'intégrisme républicain contre la laïcité:

A laicização se dá ao mesmo tempo por um refluxo social da religião e por uma transferência do religioso. No nível político, fala-se do sagrado republicano. Dever-se-ia falar também de sagrado médico (2006, p. 95).

Nas fases ascendente e hegemônica da modernidade, as instituições seculares possuem, portanto, grandes capacidades simbólicas para dar normas, sentido e esperanças (2006, p. 235).

As instituições seculares têm, neste caso, explica JB, um papel de socialização moral "para desestabilizar a instituição religiosa" (2006, p. 237). Trata-se exatamente do que eu designo por secularização-transferência. JB assinala, de fato, que esse processo de secularização, traduzindo-se em uma transferência do absoluto do religioso para o secular, foi particularmente acentuado na França:

${ }^{12} \mathrm{O}$ termo ultramodernidade foi empregado principalmente por Pierre Legendre. Em The Sage Handbook of the Sociology of Religion, o sociólogo norte-americano das religiões, Kevin J. Christiano considerou minha análise em termos de ultramodernidade, inclusive no título de sua contribuição “Assessing Modernities: From 'Pre' to 'Post' to 'Ultra' (2007). 
Parece que, na França, o processo de laicização se desenrolou conjuntamente por um refluxo social da religião [...] e por uma transferência do religioso maior que em outros países (cf. notadamente a medicina) (2006, p. 208).

Em dialética com um processo de desencantamento religioso, a laicização-secularização francesa maximizou, ao declarar os 'valores da República', os elementos estruturantes de encantamentos seculares. As expectativas sociais de sentido, normas, esperanças tiveram nitidamente maior tendência do que em outros lugares a serem transferidas para instituições como a medicina e a escola (2006, p. 96-97).

Os trabalhos de JB, aliás, me levam agora a acrescentar a medicina para explicar meu esquema de análise.

Tudo isso não me inclina em nada, como alega JB, a identificar a ultramodernidade com qualquer "fim da história" que seja. Bem pelo contrário, a imensa abertura dos possíveis que essa radicalização da modernidade representa pode suscitar ainda mais debates e conflitos porque os desafios são consideráveis (ecológico e antropológico em particular). Portanto, não tenho a menor dificuldade de concordar com JB que "possamos passar progressivamente para outro marco sociocultural". É justamente isso que defendo: há uma mudança de paradigma.

JB e eu concordamos no reconhecimento de que, neste novo regime da modernidade, pode-se falar de um "tempo em que a própria secularização se rotinizou e se desencantou", de uma laicidade secularizada (p. 74). Com razão, JB fala da "desutopização de uma secularização que se tornou estabelecida nas sociedades modernas" (2006, p. 242). É uma dimensão da secularização em ultramodernidade: depois de ter falado de "laicização da laicidade", desenvolvi, a partir de Ulrich Beck, a tese da radicalização da secularização, em que a sociedade considerada moderna aparece, ela mesma, como uma sociedade tradicional, tendo suas principais instituições (a família, o trabalho, a escola e a universidade, o político, a medicina, etc.) profundamente abaladas pelas evoluções em curso. "Depois da dominação pela religião e da dominação institucional, vivemos agora na época da dominação midiática” (2006, p. 101), escreve JB, que reconhece que "a globalização põe em crise todos os modelos" (2006, p. 113). Aliás, até mesmo os modelos das relações Igreja-Estado que se construíram historicamente em cada sociedade nacional. Quando falo "das sociedades nacionais que regularam de certa maneira, cada uma a seu modo, as relações entre o Estado e as religiões - na página 14 da minha obra intitulada $L e$ retour du religieux dans la sphère publique (2008) - refiro-me simplesmente aos dispositivos históricos das relações entre Igrejas e Estado, tais como foram 
construídos nos diferentes países da Europa, dispositivos estes que foram todos abalados pela mudança social, em particular pela europeização e pela globalização. Logo, não compreendo por que JB possa pensar que, com essa formulação, eu considero tudo resolvido!

Baubérot admite igualmente que a sociedade massificada de consumo "cria hoje a necessidade renovada de pertencimento cultural e, neste nível, a religião pode ser um recurso cultural" (2006, p. 156). Ele combate o universalismo abstrato de um fundamentalismo republicano que chega a falar da "necessidade de integrar uma dose de multiculturalismo para que as diferenças culturais sejam reconhecidas e possam ser transmitidas ou mesmo valorizadas" (2006, p. 127). Citando Sylvie Mesure e Alain Renaut (1999, p.30), ele afirma que "o reconhecimento da diferença" tornou-se, de fato, "a própria condição do reconhecimento desse universal que nos faz idênticos" (2006, p. 128). Daí a necessidade, hoje - mantendo ao mesmo tempo as aquisições da lógica da emancipação (a liberdade inerente ao indivíduo de se engajar ou desengajar, de aderir ou não aderir, de participar ou não participar) -, de se orientar para certa lógica do reconhecimento, dando "a cada um, a cada grupo, os meios de acesso a uma visibilidade social mínima, principalmente midiática", e exigindo que o político "seja o mediador da sociedade com ela mesma e deixe de se tomar por seu tutor” (Roman, 1998, p. 104-105).

\section{Nossos pontos de divergência}

Nossas divergências concernem essencialmente ao modo de analisar os três pontos seguintes: 1 - o conceito de religião civil; 2 - os discursos de Nicolas Sarkozy sobre a religião; 3 - o lugar e o papel das religiões nas sociedades democráticas contemporâneas.

\section{Sobre a questão da religião civil}

Em sua obra de 2006, L’intégrisme républicain contre la laïcité, Jean Baubérot reconheceu enfim que havia, na França, "uma religião civil rejeitada no impensado, inconfessável, constantemente trabalhada pela crítica laica de seus efeitos, mas também constantemente renascente" (p. 228). Porém, em seu panfleto antissarkozyzta, ele usa o conceito da religião civil de maneira bastante contestável, no meu entender. Ele o toma muito mais como um conceito filosófico do que como um conceito sociológico. Aliás, Baubérot cita mais Jean-Jacques Rousseau que Robert Bellah e seus epígonos que retomaram sociologicamente o conceito (Bellah, 1967; 1975; Bellah e Hammond, 1980; Kleger e Müller, 1986). Para JB, uma sociedade escolhe - ou não - uma religião civil, e a laicidade francesa caracteriza-se precisamente pela recusa 
de uma religião civil, a qual "invoca uma transcendência que furta ao debate os fundamentos do laço social, o sacraliza". Segundo ele, como Jules Ferry foi um adversário convicto da religião civil, como a Lei de 1905 foi mais democrática e liberal que republicana e anticlerical, a escolha da França foi a recusa da religião civil. Baubérot pressupõe, portanto, que uma sociedade pode prescindir de uma religião civil, podendo até mesmo decretar, por escolha político-filosófica, sua dispensa. Como veremos adiante, o problema é que a religião civil constitui um fenômeno social ligado à dinâmica coletiva das sociedades, às suas dimensões imaginária e afetiva, sendo, portanto, um fenômeno difícil de abolir de maneira voluntarista. Para JB, a religião civil é um clericalismo de Estado, afirmado através de uma República que atesta sua transcendência e seus valores, seja independentemente de qualquer referência religiosa, seja ligando-a a referências a Deus. Ele considera que a laicidade, na França, pode ser identificada à recusa da religião civil, pois trata-se da laicidade de uma democracia liberal que recusou tanto a laicidade integral de Combes e o culto autossuficiente da República (versão religião laica da República) quanto a referência a fundamentos religiosos do laço social e político. Como ele escreveu em 2004, lembrando Combes, "a atração pela religião civil tem, portanto, afinidade com uma laicidade exclusiva, uma laicidade de combate. A laicidade contida na Lei de 1905 é, ao contrário, uma laicidade inclusiva, um pacto laico que rompe com a religião civil republicana e seus aspectos excomunicatórios" (2004, p. 170). Depois de ter identificado a religião civil a uma laicidade integral e a um culto intransigente da República, JB pode então dizer que a laicidade francesa é a recusa da religião civil. O problema é que existem muitas modalidades de expressão da religião civil, com ou sem referências religiosas explícitas. A religião civil à francesa não se reduz à alternativa da França laica ou da França católica, podendo ser, no mínimo, uma mistura sutil das duas. JB acusa o Presidente de "abandonar o caminho da laicidade para tomar o da religião civil, seja ela cato-laica, ecumênico-laica ou sincreto-laica, pouco importa" (2008, p. 126). Segundo ele, o presidente Sarkozy cairia, por ter invocado Deus em seus discursos e falado positivamente das religiões, na "monstruosidade de uma religião civil americana à francesa"!

Mas o que é, então, a religião civil? De minha parte, sempre considerei a religião civil como sendo primeiramente uma ferramenta de conhecimento usada na Sociologia e nas Ciências Políticas para estudar o modo como as sociedades, organizadas em coletividades políticas, tendem a sacralizar seu estar-junto. Por serem construções históricas inevitavelmente volúveis e precárias, as sociedades têm necessidade de referir sua existência a um 
imaginário que lhes permita representar sua fundação e criar a memória de sua história através de diversos símbolos e ritos. Por meio desses símbolos e ritos, elas glorificam sua unidade e valorizam sua existência como unidade sociopolítica particular. O culto das origens desempenha, neste caso, um grande papel, principalmente evocando as lutas passadas e o sangue derramado e fazendo referência ao universal. Logo, designo o conceito de religião civil como o sistema de crenças e ritos através do qual uma sociedade sacraliza seu estar-junto e mantém uma devoção a si mesma. Trata-se de uma forma não religiosa de sagrado, embora tradições religiosas possam alimentar esse sagrado político que expressa um sentimento coletivo de unidade. A meu ver, observam-se fenômenos de devoção coletiva em todas as sociedades, pois tais fenômenos nos remetem às dimensões imaginárias e afetivas das sociedades organizadas em coletividades políticas. Como bem observou Durkheim, a sociedade produz a crença em si mesma e a ritualização desta crença. Este fenômeno toma formas muito variadas nos diferentes Estados e evolui até mesmo no modo como se manifesta num mesmo país. Sébastien Fath, por exemplo, mostrou as evoluções da religião civil americana, a qual, conforme o período, se articula diferentemente com elementos do panorama religioso norteamericano, sendo "conservadora" ou "progressista" (2004). Assim, identificar a religião civil a um fenômeno próprio dos Estados Unidos é bastante redutor. Não só porque muitos autores provaram a fecundidade do conceito, aplicando-o a outras sociedades, como também porque certos especialistas dos Estados Unidos, como Elisabeth Zoller, chegam a afirmar justamente que, como a separação das Igrejas e do Estado é muito mais rigorosa nos Estados Unidos do que na França, "a República só conseguiu afirmar-se como associação política na França moderna construindo com a laicidade, principalmente na escola, uma religião civil de que os Estados Unidos nunca precisaram" (Zoller, 2005b, p. 32). Camille Froidevaux-Metterie, por sua vez, julga que, nos EUA, "a religião civil realiza a combinação frágil, mas suficiente, do espírito de religião e do espirito de laicidade, a religiosidade pública através da qual ela se expressa satisfaz a primeira aspiração, enquanto a adesão ao modelo nacional e ao seu corpus constitucional cumpre a segunda" (2009, p. 110). Na França, é evidente que a segunda dimensão é a mais importante, o espirito de laicidade e o espírito de religião tendo estado mais em relação de concorrência do que em relação de complementaridade. No entanto - e é interessante observar aí como a religião civil se expressa e evolui na França -, pode-se considerar a hipótese de que o espírito de laicidade e o espírito de religião estejam rearticulando sua relação, tal como indicam, em minha opinião, os discursos do presidente Sarkozy (cf. infra). 
Ao aprofundar o conceito de religião civil, aplicando-o à França (Willaime, 1993, p. 571-580), propus distinguir entre uma religião cívica, centrada na devoção à unidade da coletividade política, e uma common religion, que remete ao conjunto difuso das crenças, representações e avaliações que definem o universo filosófico-religioso e ético de uma população. Essa distinção é inspirada num estudo sobre a religião civil em Israel, onde Charles Leibman e Eliezer Don-Yehiya distinguem uma religião civil de orientação política de uma religião civil de orientação social (1985, p. 169-209). Quem dirige principalmente o imaginário estruturante de uma sociedade e quais são os componentes desse imaginário? A religião civil pode manter relações muito variáveis com as religiões constituídas e representar uma questão de lutas entre as forças atuantes de uma sociedade, sejam estas forças políticas, sociais ou religiosas. Nesta perspectiva, portanto, a questão não é ter ou não ter uma religião civil, mas, sim, observar e analisar como a França expressa, tal qual qualquer outra sociedade, uma religião civil e quais são os elementos que intervêm nas ritualizações e simbolizações através das quais ela se manifesta. A análise das diferentes sequências da religião civil à francesa permite justamente revelar um sincretismo laico-cristão na gestão do imaginário nacional e na evolução para uma recomposição ética da religião civil em torno de um ecumenismo dos direitos humanos. Do meu ponto de vista, a religião civil é um objeto social evolutivo e seguidamente conflituoso. Pergunto-me, em particular, qual é o papel das culturas religiosas dominantes ou de um misto filosóficoecumênico na afirmação de uma identidade coletiva. Segundo JB, "a laicidade deve cuidar para não se transformar numa religião civil que tenta recorrer a um fechamento transcendente do laço social. Duas versões dessa religião civil devem ser evitadas: a versão dita republicana, em que a transcendência nada mais é que a transcendência em si; e a versão americana, em que essa transcendência se põe acima das normas que a República pretende encarnar" (2008, p. 219). Será que podemos dizer que os discursos do presidente Sarkozy não são laicos por "se situarem na mesma linha da religião civil"? (2008, p. 62) Eles expressam, sem dúvida, elementos de religião civil, assim como os discursos dos predecessores de Sarkozy, de direita ou de esquerda. Por isso, é necessário analisar de forma comparativa e diacrônica um corpus de discursos presidenciais para examinar como cada um deles articulou a religião civil de tipo francês. É preciso observar atentamente o modo como cada presidente se referiu, mais ou menos explicitamente, às tradições religiosas presentes na sociedade francesa. Embora seus predecessores não tenham ignorado essas tradições - François Mitterrand, em particular - é verdade que o presidente Sarkozy a elas se referiu de maneira mais direta e explícita, 
especialmente em seus discursos em Latrão e em Riad. Não haveria, na França, especialmente desde a Revolução Francesa, uma dificuldade bastante específica para simbolizar a unidade nacional? Nesse exercício, as autoridades públicas parecem não saber o que fazer com as dimensões religiosas de nossa cultura e de nossa história, sobretudo porque essas dimensões estiveram ligadas a conflitos. Assim, contrariamente a muitos outros países onde essas dimensões, estando mais ou menos integradas no imaginário nacional, evoluem ao ritmo da secularização e das reconfigurações do panorama religioso, na França, elas constituem objeto de discórdias. A França tem uma relação complicada e conflituosa com as dimensões religiosas de sua história e de sua cultura.

\section{Sobre a análise dos discursos de Nicolas Sarkozy}

A análise feita por JB dos discursos de Nicolas Sarkozy, pronunciados no Palácio de Latrão, em Roma, em 20 de dezembro de 2007, e em Riad (Arábia Saudita), em 14 de janeiro de 2008, é, para mim, partidária e política. JB viu nesses discursos a manifestação de um "neoclericalismo" e de uma "contestação da laicidade". Essa análise não leva absolutamente em conta os lugares e as condições de enunciação dessas alocuções diplomáticas, que não foram pronunciadas em Paris, mas em Roma, numa basílica, e em Riad, em território muçulmano. Foi no âmbito de um discurso dirigido a católicos e num lugar católico que o presidente Sarkozy lembrou a importância histórica e cultural das relações entre a França e o catolicismo. Foi em terra muçulmana que ele exaltou "o Deus único das religiões do Livro", valorizou a diversidade das religiões e das culturas e defendeu um "islã aberto". Trata-se de discursos diplomáticos e políticos pronunciados em circunstâncias muito específicas. Eu falei de teologia diplomática. Uma das diferenças em relação aos seus antecessores é que Sarkozy manifesta em seus discursos uma posição mais pessoal sobre a religião. Numa comparação dos discursos de N. Sarkozy com as declarações de François Mitterrand sobre as questões religiosas, Paul Airiau faz uma observação pertinente: "aquilo que faziam seus antecessores como indivíduos quando eram presidentes, sabendo, portanto, que suas posições pessoais não passariam despercebidas, Sarkozy faz enquanto presidente que assume o indivíduo." Paul Airiau indaga: "Será que Nicolas Sarkozy rompeu com a laicidade entendida como realidade jurídica, como ideologia, como fenômeno sócio-histórico? Sem sequer recorrer à história, a resposta já é negativa nos três casos", afirma Paul Airiau (2008, p. 86), assim como eu. E se desejarmos recorrer à história, Paul Airiau indica que Nicolas Sarkozy se insere na tradição de certa prática republicana que, em 
1938-1939 (ibidem, p. 93) ${ }^{13}$, por exemplo, exerceu a laicidade positiva. Uma tradição que Jacques Chirac também seguiu, com sua vontade de encontrar os responsáveis religiosos, principalmente os católicos, na sua primeira passagem por Matignon (naquela época, as reticências foram expressas pela Igreja católica), iniciativa esta que Lionel Jospin vem a tomar em 2002.

Em vez de julgar os discursos de Sarkozy com base numa concepção normativa da laicidade, prefiro adotar uma perspectiva comparativa com discursos de seus antecessores. Quando recebeu o papa João Paulo II em Lurdes, em 1983, o presidente Mitterrand dirigiu-se ao Soberano Pontífice nos seguintes termos: "Desejo cumprimentar em sua pessoa a instituição que marcou tão profunda e intimamente a história do meu país e que permanece uma fonte viva, na qual tantos dos nossos continuam a buscar suas razões de ter esperanças". François Mitterrand que, diante do crescimento da extrema direita, não hesitou em solicitar abertamente, durante o segundo turno de sua campanha eleitoral presidencial, o voto dos cristãos, lembrando, num discurso em Lille, em 29 de abril de 1988, "o ensinamento de Cristo" que era "a igualdade profunda dos homens e das mulheres entre si". Quando recebeu, no Palácio do Eliseu, em 23 de junho de 2003, os representantes da francomaçonaria francesa, o presidente Chirac assinalou e exaltou "o indefectível vínculo dos franco-maçons com a República". Por que razão outras famílias espirituais não poderiam também ouvir da boca de um presidente da república o reconhecimento por suas contribuições? Tocamos aqui, penso eu, na importante evolução que o discurso de Nicolas Sarkozy representa, evolução esta que choca todos aqueles que não entenderam que vivemos hoje numa conjuntura totalmente diferente daquela do momento de 1905 que separou as Igrejas e o Estado. Não é mais uma conjuntura em que a República, tendo de se fortalecer ante os riscos recorrentes do clericalismo, praticava uma laicidade de desconfiança em relação ao religioso, e, sim, uma conjuntura em que a separação das Igrejas e do Estado está definitivamente assegurada tanto no plano jurídico como no plano sociológico, tornando possível considerar abertamente, sem renegar a laicidade, as contribuições espirituais, educativas, sociais, culturais das religiões. Na conjuntura ultramoderna, em que mesmo as esperanças seculares foram secularizadas e os cidadãos estão em busca de

\footnotetext{
${ }^{13}$ Época em que o vice-presidente do Conselho, Camille Chautemps, alegrava-se por uma "ampla cooperação voluntária" entre o Estado e a Igreja e o presidente da Câmara dos Deputados, Édouard Herriot, reagiu nos seguintes termos ao falecimento do papa Pio XI, em 10 de fevereiro de 1939: "A Câmara dos Deputados francesa inclina-se com respeito e reconhecimento perante o pontífice [...] que protegeu os títulos do espírito contra as pretensões da matéria e que permanece, seguindo a tradição dos grandes papas, um dos mais elevados e puros representantes desta potência invencível que é a consciência".
} 
recursos para suas convicções, Nicolas Sarkozy compreendeu que se podia praticar abertamente uma laicidade de diálogo com as religiões, uma laicidade que as integra positivamente no viver-junto em democracia. Ele pôde fazê-lo principalmente porque essa laicidade de reconhecimento e de diálogo já é muitas vezes praticada, sobretudo em escala local, e essa compreensão da laicidade está em sintonia com a Europa. Situando esses discursos de Sarkozy na passagem de uma laicidade de separação a uma laicidade de reconhecimento, Paul Airiau, que também faz referência às análises de Philippe Portier, não vê nos discursos presidenciais uma contestação da laicidade. O fundamento das coisas não foi modificado: "o religioso não dita mais as regras da vida em comunidade". A laicidade positiva de Nicolas Sarkozy não o impede de bater de frente com a Igreja católica em diferentes assuntos, como, por exemplo, o trabalho nos domingos.

Num artigo da revista Esprit dedicada ao tema Qu'est-ce que le sarkozysme?, Jean-Louis Schlegel (2007, p.159-161) analisou essa postura sarkozysta em relação às religiões, apontando, sobretudo, sua adequação à conjuntura religiosa e política da França contemporânea. Philippe Portier também o faz num artigo da mesma revista (2008, p. 198). Quaisquer que sejam as críticas que possam ser feitas aos discursos de Sarkozy sobre a religião, é interessante constatar, de um ponto de vista sociológico, que essa postura perante as religiões está em sintonia com a ultramodernidade e com a laicidade de reconhecimento e de diálogo que prevalece em escala europeia. Por detrás do interdito de palavras positivas sobre a religião que JB aponta ao Presidente da República, encontra-se, na verdade, a clássica desconfiança francesa em relação à crença religiosa herdada da Revolução ${ }^{14}$. Ora, expressando-se como fez, Nicolas Sarkozy oficializa a passagem de uma neutralidade de desconfiança a uma neutralidade de confiança, de uma neutralidade mais negativa a uma neutralidade mais positiva: sem dúvida, é neste sentido que ele manifesta uma ruptura relativa em relação a seus antecessores (muitos destes pensavam assim, mas não diziam oficialmente). O que incomoda JB é o fato de que o presidente de uma República laica possa considerar positivamente o papel da religião dentro de uma democracia, que possa deixar de pensar "a relação do político com a crença nos mesmos termos que o fizeram os fundadores da Terceira República" (ibidem, p. 196).

\footnotetext{
${ }^{14}$ Claude Langrois, depois de ter observado que, na Declaração Universal dos Direitos do Homem e do Cidadão de 1789, é "unicamente em benefício - se assim podemos dizer - da religião que a perturbação da ordem pública retorna", assinala que os Constituintes "inserem, portanto, nesse texto libertador uma suspeita em relação à religião que visa diretamente o "poder nocivo do catolicismo", mas que se revela específica da tradição francesa", "Révolution et religion, pratiques et principes" (Langlois, Willaime, Châtelier, 2009, p. 225).
} 


\section{Acerca do religioso na vida pública}

Em 2005, fui levado a fazer algumas observações críticas sobre a Declaração internacional sobre a laicidade ${ }^{15}$, em particular, sobre o Artigo 14, que afirma a necessidade de "desligar o religioso das evidências sociais". No âmbito das democracias liberais, compreende-se a necessidade, também afirmada pelo citado Artigo 14, de desligar o religioso "de qualquer imposição política", mas por que desligá-lo "das evidências sociais"? O Estado é laico, não a sociedade. Esta é o que é, mais ou menos secularizada, mais ou menos impregnada por uma cultura religiosa majoritária e por culturas religiosas minoritárias que marcaram sua história e sua relação com o mundo. Querem abolir a common religion das populações por decreto e militantismo emancipatório? Ao passar do político ao social, a Declaração não abandonou totalmente, a meu ver, uma dimensão de luta contra a religião.

O outro ponto em que discordo de meu amigo JB concerne à interpretação que ele faz de qualquer consideração pública das religiões. Por detrás da referência às heranças religiosas nos preâmbulos da Carta dos Direitos Fundamentais e do Tratado Constitucional Europeu, JB vê o risco "de que as instituições europeias tenham de se inspirar mais ou menos nessa herança e de que as normas religiosas não [sejam] totalmente dissociadas das normas civis" (2004, p. 183). Como se reconhecer a contribuição das heranças religiosas fosse submeter-se aos poderes da religião e como se as instituições europeias deixassem de ser laicas por reconhecerem que a Europa é devedora também por essas heranças religiosas. Eu considerei, ao contrário, que, mencionando suas "heranças culturais, religiosas e humanistas", a Europa estava cumprindo um verdadeiro pacto laico. JB teve a mesma reação no que diz respeito ao artigo do Tratado Constitucional Europeu, mantido no Tratado de Lisboa. Ele contesta o fato de que se tenha reservado um artigo especial para as religiões: "mas por que então ter dissociado Igrejas e outras associações, mencionadas em outro artigo? Se as Igrejas se põem, por menos que seja, acima da sociedade civil, em vez de fazer parte dela, então o clericalismo mostra sua cara" (2004, p. 183). Como se reconhecer a especificidade das religiões e das organizações filosóficas nas sociedades e propor manter com elas "um diálogo aberto, transparente e regular" significasse que essas organizações religiosas e filosóficas estão acima da sociedade civil e são capazes de impor suas normas! Por que recusar um artigo reservado especialmente às religiões num texto europeu, uma vez que a França, através da Lei de 1905, através de

\footnotetext{
${ }^{15}$ Encontramos essas observações, sem indicação de autor, nas páginas 262-264 do livro de Jean Baubérot: L'intégrisme républicain contre la laïcité (2006).
} 
suas associações culturais e diocesanas (sem falar de outros textos e estatutos relativos, por exemplo, às congregações), previu, dentro de toda a laicidade, dispositivos jurídicos específicos para as religiões?

Em seu texto Laïcité expliquée à M. Sarkozy (2008), JB critica, seguindo a mesma linha, a escolha feita por Lionel Jospin, em fevereiro de 2002, de dialogar a cada ano com os representantes da Igreja católica. JB considera essa iniciativa ambígua do ponto de vista laico por julgar contestável não o diálogo, mas seu aspecto institucional: "isso provoca um curto-circuito muito pouco laico", afirma ele. No entanto, o que me interessa aqui é a análise subjacente a essas escolhas. Tenho dificuldade de entender JB quando ele deseja restringir completamente as religiões à sociedade civil e suas associações, como se as organizações religiosas, participando plenamente da sociedade civil, não tivessem especificidades e como se a liberdade religiosa e seu exercício não constituíssem uma dimensão específica, explicitamente reconhecida pelos Estados e pelas instituições europeias. Segundo JB, “os recursos simbólicos e culturais que as religiões oferecem, assim como as culturas, constituem uma dimensão do indivíduo, mas nunca devem englobá-lo" (2008, p. 104). Por que razão o fato de uma sociedade democrática e laica garantir que cada indivíduo tenha o direito de possuir ou não uma religião, o direito de dispor livremente ou de mudar de religião, deveria implicar essa concepção puramente individualista das religiões? Nem o Artigo 4 da Lei de 1905, que obriga as associações culturais a "respeitar as regras gerais de organização do culto a que se propõem exercer", nem o Artigo 9 da Convenção Europeia dos Direitos do Homem reduzem o fenômeno religioso às suas dimensões puramente individuais. Em sua obra de 2006, JB reconhece que as regras citadas no Artigo 4 da Lei de 1905 "implicam, portanto, para o catolicismo, o respeito da hierarquia" (p. 150). Ele acrescenta: "Essa Igreja é, pois, concebida como uma entidade independente dos membros que a compõem, um agrupamento intermediário entre os fiéis (indivíduos cidadãos) e o Estado" (2006, p. 152). Citando Philippe Lazar (2003, p. 111 et. seq.), JB chega a reconhecer que "todo fato de cultura - a catolicidade, a judeidade, a islamidade, a corsitude ${ }^{16}$, etc. - pode ser interpretado como um bem público global pertencente ao patrimônio cultural da humanidade" (2006, p. 129) e que "as culturas possuem sua consistência própria, constituindo, assim, recursos para não serem vítimas da sociedade mercantil massificada e padronizada, mas, ao mesmo tempo, não permanecem estáticas, enriquecem-se elas mesmas com a contribuição dos indivíduos que delas se apropriam" (2006, p. 129). Em 2006, para JB, as religiões são

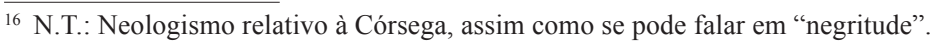


culturas, enquanto, em 2008, ele considera apenas os indivíduos. Sua análise e suas reações que concebem em termos de clericalismo qualquer consideração pública das religiões parecem-me, portanto, deslocadas em relação à conjuntura atual. Estaria ele esquecendo, levado por sua paixão laica, que as religiões encontram-se antes enfraquecidas socialmente nas sociedades europeias contemporâneas e que suas populações estão profundamente secularizadas, embora se identifiquem com uma religião? Estaria ele esquecendo que não se acredita mais no político como se acreditava na virada dos séculos XIX e $\mathrm{XX}$ e que a soberania nacional não é mais o que era? É evidente que JB sabe $\mathrm{e}$, inclusive, trata de tudo isso em alguns de seus escritos. Mas por que isso não brota mais em sua análise e em suas reações em matéria de laicidade? $\mathrm{O}$ que ele deseja manter é quase a intangibilidade de um dogma forjado em 1905. Talvez isso se deva ao vaivém constante que ele faz entre 1905 e 2005 , como se pudéssemos passar tão facilmente do momento de 1905 aos anos contemporâneos, dois períodos ligados a contextos políticos, religiosos e socioculturais muito diferentes. Embora isso gere resistências e dificuldades, a França está, de fato, engajada num novo regime da ação pública em que o Estado tem um papel central menos importante. O Estado está "em vias de desdiferenciação", no dizer de Philippe Portier (2003, p. 22). "Portador da transcendência republicana, ele se punha, antes, acima da sociedade, banindo, assim, a instância religiosa da esfera pública. Ora, esse modelo desaparece: o político se abre cada vez mais para o social e multiplica desse modo as zonas de contato com as Igrejas.” Desejaríamos que JB incluísse em suas análises a constatação tão pertinente de Pierre Manent: "Quando a nação deixa de ser concebida como comunidade sagrada, é a vez do Estado laico ser laicizado, passando a ser apenas um dos inúmeros instrumentos de governança" (2006, p. 78). Em recente contribuição (2009, p. 47-63), Philippe Portier conclui que a França atual, assim como os outros países da Europa, "pretende dar à fé um lugar na esfera pública de Estado que a República das origens lhe recusava" (ibidem, p. 62)17. Ele assinala com pertinência: "A despeito de sua constitucionalização em 1946 e, novamente, em 1958, a laicidade não parou de se transformar. Concebida, há um século, para relegar o religioso ao espaço privado, eis que ela o acolhe solenemente, sob as condições estabelecidas, com as honras do Palácio da República" (ibidem, p. 63). Estou certo de que JB julga em demasia as evoluções da laicidade, que são o que são e devem ser descritas e analisadas tal como se apresentam, a partir de um ponto de vista normativo

\footnotetext{
${ }_{17}$ No capítulo das condições, Philippe Portier observa que "a República exige agora das religiões, e cada vez com maior rigor, que elas se mantenham no círculo dos princípios de liberdade e de igualdade sobre os quais repousa a sociedade democrática" (2009, p. 61-62).
} 
baseado em sua análise do momento histórico de 1905. Ele opõe Jules Ferry e Aristide Briand a Nicolas Sarkozy, como se a fidelidade a uma determinada sequência histórica e aos seus eminentes atores fosse a norma. Como outros autores, prefiro ressituar a evolução da laicidade francesa na conjuntura da ultramodernidade contemporânea. Quanto à crítica que me é dirigida por JB em suas considerações sobre "esfera pública, espaço público, esfera privada", direi simplesmente duas coisas: 1- A esfera pública não se reduz ao domínio da soberania e da regulação estatal, ela inclui também a mídia, as instituições e as associações, todos os grupos intermediários da sociedade civil; 2- como bem explicou Étienne Tassin (2008, p. 113-134), é importante fazer a distinção entre espaço público e espaço comum, o domínio público sendo, por definição, heterogêneo, pois "a comunidade política não é a reduplicação do princípio comunitário a uma potência superior" (ibidem, p. 130).

JB me acusa de falar de dois "poderes" quando me refiro ao político e ao religioso. Falar deles não é absolutamente adotar uma posição normativa, é uma constatação e um princípio de inteligibilidade bem destacado por Max Weber: as diversas formas espirituais de dominação estarão sempre em tensão ou em conflito com as dominações políticas. Como enfatizo na conclusão da minha obra (Willaime, 2008, p. 108), "a separação dos poderes políticos e religiosos implica, de fato, estruturalmente, a existência de tensões e conflitos. Estes são normais na democracia, constituem até mesmo a mola propulsora da vida democrática. Quer sejam gerados, hoje, cada vez mais pelos limites atribuídos pelo político aos poderes religiosos, quer digam respeito aos limites atribuídos pelo religioso aos poderes políticos, esses conflitos manifestam tensões significativas e produtivas na democracia. Protegem a sociedade tanto do risco da dominação espiritual do político quanto do risco da dominação temporal do religioso".

Ainda que o panfleto contra o presidente Sarkozy termine pela afirmação de que "uma laicidade viva não pode mais se situar no despotismo esclarecido do Estado-nação que as Luzes privilegiavam, devendo ser uma laicidade vinda de baixo, enraizada na diversidade pluricultural da sociedade civil" (2008, p. 246), Jean Baubérot não inclui em suas análises essas mutações do papel do Estado, tampouco os efeitos da ultramodernidade, sequer o impacto da transnacionalização. Ele tende a pensar a laicidade de 2008 com uma projeção excessivamente direta do momento de 1905 para o século XXI e com base num esquema nacional que não leva suficientemente em conta a europeização. Isso é ainda mais lamentável pelo fato de que ele militou muito a favor de uma internacionalização da laicidade, muitas vezes reagindo e polemizando contra o sectarismo e o fundamentalismo de certos defensores da laicidade. No 
entanto, ele fala de uma "saída social do projeto das Luzes", prova manifesta de sua plena consciência de que, neste início do século XXI, há mesmo uma mudança de paradigma.

\section{Referências}

AIRIAU, Paul. La difficile «laïcité positive». Liberté politique, Paris, 43, p. 85-96, dez. 2008 .

BAUBÉROT, Jean. Laïcité 1905-2005, entre passion et raison. Paris: Seuil, 2004.

l'Aube, 2006.

L'intégrisme républicain contre la laïcité. La Tour d'Aigues: Éditions de

La laïcité expliquée à M. Sarkozy... et à ceux que écrivent ces discours. Paris: Albin Michel, 2008.

BECKFORD, James A.; DEMERATH III, N.J. (eds.) The sage handbook of the sociology of religion. London: Sage Publications, 2007.

BELLAH, Robert N. Civil religion in America. Daedalus, Journal of American Academy of Arts and Sciences, Boston, v. 96, n. 1, 1967.

. The Broken Covenant. American civil religion in time of trial. New York: The Seabury Press, 1975.

BELLAH, Robert N.; HAMMOND, Phillip E. Varieties of civil religion. San Francisco: Harper \& Row Publishers, 1980.

CHRISTIANO, Kevin J. Assessing modernities: from "pre" to "post" to "ultra". In: BECKFORD, James A.; DEMERATH III, N.J. (eds.) The sage handbook of the sociology of religion. London: Sage Publications, 2007. p. 39-56.

FATH, Sébastien. Dieu bénisse l'Amérique: La religion de la Maison Blanche. Paris: Seuil, 2004.

FROIDEVAUX-METTERIE, Camille. Politique et religion aux États-Unis. Paris: La Découverte, 2009.

GREENHOUSE, Carol J. La séparation de l'Église et de l'État aux États-Unis: traduire ou trahir? In: ZOLLER, E. (dir.). La conception américaine de la laïcité. Paris: Dalloz, 2005. p. 201-210.

KLEGER, Heins; MÜLLER, Alois (eds.). Religion des bürgers: zivilreligion in Amerika und Europa. München: Kaiser Verlag, 1986.

KOENIG, Mathias; WILLAIME, Jean-Paul (eds.). Religionskontroversen in Frankreich und Deutschland. Hamburg: Hamburger Edition, 2008.

LANGLOIS, Claude. Révolution et religion, pratiques et principles. In: LANGLOIS, Claude; WILLAIME, Jean-Paul; CHÂTELLIER, L. (dirs.). Lumières, religions et laïcité. Paris: Riveneuve Éditions, 2009, p. 219-226.

LAZAR, Philippe. Autrement dit laïque. Paris: Liana Levi, 2003.

LEIBMAN, Charles S.; DON-YEHIYA, Eliezer. The dilemma of reconciling traditional culture and political needs: civil religion in Israel. In: KRAUSZ, E. (ed.). Studies of Israel Society III, 1985. p. 196-209. 
LIVRE blanc sur le dialogue interculturel: vive ensemble dans l'égale dignité. Strasbourg, Conseil de l'Europe, 2008.

MANENT, Pierre. La raison des nations: réflexions sur la démocratie en Europe. Paris: Gallimard, 2006.

MESURE, Sylvie; RENAUT, Alain. Alter ego: les paradoxes de l'identité démocratique. Paris: Flammarion, 1999.

PORTIER, Philippe. De la séparation à la reconnaissance: l'évolution du régime français de laïcité. In: ARMOGATHE J.R.; WILLAIME, J.P. (dirs.). Les mutations contemporaines du religieux. Turnhout: Brepols, 2003. p. 1-24.

Retour sur la "laïcité positive" de Nicolas Sarkozy: néocléricalisme ou ultramodernité? Esprit, 5, p. 196-198, 2008.

La régulation étatique du religieux en France (1880-2008): Essai de périodisation. In: FORET, Fr. (éd.). Politique et religion en France et en Belgique. Bruxelles: Éditions de l’Université Libre de Bruxelles, 2009. p. 47-63.

ROMAN, Joël. Qu'est-ce qui fait lien? In: WEYDERT, J. (dir.). Fragile démocratie. Politique, cultures et religions. Paris: Bayard Éditions, 1998. p. 104-105.

SCHLEGEL, Jean-Louis. La question religieuse: relier la politique et l'espérance? Qu'est-ce que le sarkozysme? Esprit, v. 11, p. 155-162, 2007.

TASSIN, Étienne. Espace commun ou espace public? L'antagonisme de la communauté et de la publicité. In: DACHEUX, E. (coord.). L'espace public. Paris: CNRS Éditions, 2008. p. 113-134.

WILLAIME, Jean-Paul. La religion civile à la française et ses métamorphoses. Social Compass, v. 40, n. 4, p. 571-580, 1993.

1905 et la pratique d'une laïcité de reconnaissance sociale des religions. Archives de Sciences Sociales des Religions, v. 129, p. 67-82, 2005.

La sécularisation: une exception européenne? Retour sur un concept et sa discussion en sociologie des religions. Revue Française de Sociologie, v. 47, n. 4, p. 755-783, 2006a.

Religion in ultramodernity. In: BECKFORD, J.A; WALLIS, J. (eds.). Theorising Religion: Classical and Contemporary Debates. Aldershot: Ashgate, 2006b. p. 73-85.

Le retour du religieux dans la sphère publique. Vers une laïcité de reconnaissance et de dialogue. Lyon: Éditions Olivétan, 2008.

WOEHRLING, Jean-Marie. Réflexions sur le principe de neutralité de l'État en matière religieuse et sa mise en œuvre en droit français. Archives de Sciences Sociales des Religions, n. 101, p. 31-52, 1998.

ZOLLER, Elisabeth (dir.). La conception américaine de la laïcité. Paris: Dalloz, 2005a.

La laïcité aux États-Unis ou la séparation des Églises et de l'État dans la société pluraliste. In: ZOLLER, E. (dir.). La conception américaine de la lä̈cité. Paris: Dalloz, 2005b. p. 3-32. 